\title{
The Effect of Brainstorming Method on Problem Solving in Our Best Friend Environment Theme
}

\author{
U. Zuhdi \& Maulidyana \\ Universitas Negeri Surabaya \\ Surabaya, Indonesia \\ ulhaqzuhdi55@yahoo.com
}

\begin{abstract}
The purpose of this study is to find out the influence of brainstorming method to problem solving skill on social studies in Gempol 3 Primary School Pasuruan. This study is a quantitative study with Quasi Experimental Design in the form of Non-Equivalent Control Group Design. This study use three main ways: pre-test, treatment, and post-test. Samples are taken with random sampling technique. The data collection uses test, while the data analysis uses t-test experiment. That result shows that there is significance influence of the use of brainstorming method to students' problem solving skill.
\end{abstract}

Keywords—problem solving skill, brainstorming method

\section{INTRODUCTION}

Education contains a teaching-learning process, with a new paradigm that recently known as learning. Understanding of learning is an interaction activity between students and teachers to convey knowledge values and attitudes in the process of education in the classroom. Learning activities in basic education units should be directed so can challenge, give fun, and motivate students to participate, provide creativity enhance independence opportunities to develop students' potential.

Education in the 21st century is required to emphasize the critical thinking and problem solving, creativity and innovation, communication, collaboration, and global awareness (Marjohan, 2013: 77). The five aspects, problem solving or problem solving becomes one of the priority aspects in education. Problem solving is an attempt to find a way out of a difficulty to achieve the previously acquired goals into the new condition. It is said to have problem-solving skills when one is able to identify problems, formulate problems, hypothesize problems, analyze data and find solutions to problems. The goals of Indonesia's education have been in line with the 21 st century education priorities.

According to Gunansyah (2015: 9), each field of study has the domain of teaching materials, namely the knowledge knowledge, skills, and attitude. As the same, with the current 2013 curriculum learning. Although learning now is not separated as in the previous curriculum, but still in one lesson that is in the 2013 curriculum integrated with other subjects. Among them there is a social studies learning content content. In the skill domain in social studies has the goal to develop the skills include: (1) thinking skills that include critical thinking, creative thinking, problem-solving thinking, and decisionmaking thinking; (2) academic skills; (3) social skills; (4) cooperation and participation skills; (5) media and ICT literacy (Information Communication Technology) skills; and (6) communication skills.

The results of the PISA (Program for International Students Assessment) and TIMSS (Trends in International Mathematics and Science Study) survey showed that Indonesian students' ability in problem solving is poor. This is evidenced by the data released by both surveys in 2016 that showed the position of Indonesian students in the lowest 10 ranking. Surveys were conducted with the aim of knowing how far students can apply the lessons they have learned.

Problem-solving skills need to be trained and developed since childhood, especially at elementary school level. Teachers require students to learn and solve problems, but do not provide guidance on how to solve the problem which is part of the problems faced today in teaching (Arend in Trianto, 2011: 66). The author wants to prove whether the problem occurs in schools that are pilot schools or not. Finally, the author chose Gempol 3 State Primary School Pasuruan as a place to be used as a research location.

In a preliminary study conducted on Monday, February 1, 2018 at Gempol 3 State Primary School Pasuruan, the author found the interaction of teachers with students in learning and demanding students to solve problems. In an interview conducted with one of the class $\mathrm{V}$ teachers, the teacher conveyed about the conditions at the time of the lesson. Teachers said that the learning methods that are used are lecture, discussion, and question and answer. Teachers rarely involve students directly in solving problems, less related to real life, and poor problem solving strategies are used, making learning less attractive and students feel less challenged while following the lesson.

From the description, the students need to be trained with problem solving skills to be able to resolve if having various social problems that existed in the community. As we know a lot of problems that exist due to economic activities in our country. In theme 8 "Environment of Our Friends" there is learning that contains social studies materials. The lesson discusses the economic role of the people's welfare. The material is very closely related to daily life that must be experienced by students. To practice problem solving skills students need an appropriate learning method, one of which is the brainstorming method.

Brainstorming or brainstorming is a method of collecting large numbers of ideas from a group of people in a short time 
to express their ideas (Sani, 2014: 203). The advantages of brainstorming methods are to train students to think actively, to think fast, to be logical, and to increase student participation in receiving lessons (Roestiyah, 2012: 74). Brainstorming methods can be used in learning activities because it is active, fun and practice problem-solving skills on every lesson. The use of appropriate methods in social studies in teaching materials can support the achievement of learning objectives. Brainstorming methods aimed at combining different ideas from students are then drawn to the conclusion to solve the problem by the students themselves.

Based on the above description, it can be concluded that learning materials that contain social studies materials also require learning methods that can help students to solve problems. Therefore, researchers are encouraged to apply the brainstorming method to find out whether the method affects the problem-solving abilities of social studies learning subjects. In fullfilling those needs, the research was proposed under the title "The Influence of Brainstorming Methods on Problem Solving on Content of Social Studies 8th theme "The Environment of Our Friends" Gempol 3 State Primary School Pasuruan".

According Sani (2014: 158), the method of learning when understood is a way used in implementing the learning strategy that has been chosen. Teacher used the method in learning has aim to create a pleasant learning environment and as a basis for teacher and student activity. According to Hamiyah and Jauhar (2014: 49), methods in learning have scope, among them (1) giving encouragement, (2) creating interest in learning; (3) delivering teaching materials; (4) increasing an atmosphere of learning; (5) fostering creativity; (6) encouraging individual improvement of learning activities and outcomes; and (7) encouraging in refining learning outcomes.

According Sani (2014: 203), brainstorming methods are a number of ideas gathered from a group of people in a short time. The purpose of the brainstorming learning method is to express what the student thinks thoroughly in response to and solve the problems given by the teacher in the classroom (Roestiyah, 2012: 74).

According Sani (2014: 204), in implementing the brainstorming method there are some rules as follows; (1) is prohibited from criticizing; (2) relax and free; (3) focused on the quantity of ideas; (4) record ideas; (5) incubation before evaluating. The stages of brainstorming method when ideas are collected and evaluated are the brainstorming rules and topics studied are explained by the teacher, the notes assigned to record teachers' ideas, the teacher motivates the students in the opinion, the breaks are given, and the minutes show the notes made; and choose relevant ideas by analyzing and evaluating ideas with teacher guidance.

According to Roestiyah (2012: 74), the advantages of brainstorming methods are opinions expressed by students with active thinking, students are trained to think fast and logical, encourage students to think according to the problems given teachers, student participation in receiving lessons increases, friends and teachers provide assistance for students who are less active, lead to healthy learning competition, students feel happy and free when issuing opinions, and can create an atmosphere of democracy and discipline.

According to Gunansyah (2015: 59), problem solving provides students with experience to search for and direct issues by using the knowledge and skills they already possess. The purpose of problem solving in the learning process can provide a firm grounding for students to think actively. The indicators of successful in problem solving is to understand the problem, design the solution, the problem is solved based on the plan being made, and the steps that have been done are checked.

The essence of Social Studies is an applied science that is very useful because it is able to provide knowledge and a very broad understanding to the students so that later students can interact with the environment, ready to interact with real social life with various social problems, and form a good student personality. The scope of Social Studies learning in primary schools is limited to social issues in daily life. The limitation of the scope of Social Studies aims to adjust the ability of students at every level, because Social Studies has a very extensive study. So for elementary school students a lot of material that introduces about life and social problems that exist in the community in order to later students can be a person capable of addressing every social problem that appears in the surrounding environment. The material is certainly adjusted to the level of ability and interest of students.

The purpose of Social Studies in elementary school is to assist and guide students' ability to develop critical and creative thinking skills in order to understand and solve problems that occur in society and to form student personality into good citizens.

\section{METHOD}

The design of research design used in this research is Quasi Experimental Design using Non-equivalent Control Group Design research design. In this study, researchers used simple random sampling technique. The simple random sampling technique is done by giving the same possibilities for the individual who is the member of the research sample. The way used to get the sample in this research is through the lottery. Where class V Flamboyan was selected as the experimental class and class V Kemuning was selected as the control class with the total number of 59 students. The design of Nonequivalent Control Group Design formulated as the table below:

TABLE1

Non-equivalent Control Group Design

\begin{tabular}{|c|c|c|}
\hline Pre-test & Treatment & Post-test \\
\hline O1 & $\mathrm{X}$ & $\mathrm{O} 2$ \\
\hline $\mathrm{O} 3$ & - & $\mathrm{O} 4$ \\
\hline
\end{tabular}


Annotation:

$\mathrm{O}_{1}$ : Experiment class pretest result

$\mathrm{O}_{3}$ : Control class pretest result

$\mathrm{X}$ : treatmen with brainstorming method

$\mathrm{O}_{2}$ : Experiment class post-test result

$\mathrm{O}_{4}$ : Control class post-test result

In this study the population is the entire class V SDN Gempol 3 Pasuruan with the number of students 88 students. With details of 30 students from class V Matahari, 30 students from class V Kemuning, and 29 students from class V Flamboyan. In this study, researchers used simple random sampling technique. The simple random sampling technique is done by giving the same possibilities for the individual who is the member of the research sample. The way used to get the sample in this research is through the lottery. Where grade $\mathrm{V}$ Flamboyan was selected as the experimental class and class V Kemuning was selected as a control class with a total of 59 students.

The independent variable in this research is brainstorming method. The dependent variable in this research is student problem solving skill. The control variables in this study were students, teachers, teaching material, and time allocation. The operational definitions of this experimental research are brainstorming, problem solving and Social Studies. The instrument of this research is the test sheet. The technique of collecting data in this study is test.

Data analysis techniques used consist of validity test and reliability test. Validity test is calculated using SPSS 22 with product moment correlation technique. With the following criteria: If rcount is $\leq$ rtable, then the item of question or statement is invalid. If rcount is ${ }^{>}$rtable, then the statement is declared valid.

Test reliability uses SPSS 22 and Cronbach 'Alpha formula as follows:

$$
r 11=\left(\frac{n}{n-1}\right)\left(\frac{\Sigma \mathrm{Si}^{2}}{\mathrm{St}^{2}}\right)
$$

(Sundayana, 2010:69)

Annotation:

$$
\begin{array}{ll}
\mathrm{r}_{11} & =\text { instrument realibility } \\
\mathrm{n} & =\text { items number } \\
\sum \mathrm{S}_{\mathrm{i}}{ }^{2} & =\text { items variant total } \\
\sum \mathrm{S}_{\mathrm{t}}{ }^{2} & =\text { total variant }
\end{array}
$$

Test reliability criteria with Cronbach's Alpha formula is $r$ count $>r$ table, the measuring tool is reliable and vice versa, if $\mathrm{r}$ count $<\mathrm{r}$ table, then the measuring tool is not reliable.
The technique of result analysis is using normality test, homogeneity test, and hypothesis test. Normality test used in this study is Kolmogorov-Smirnov. Calculation of normality test using SPSS 22. Test homogeneity using SPSS 22 on Levene test. Hypothesis test using t-test which in its calculation using SPSS 22 with Independent Simples T-Test formula.

Furthermore, if the results of $t$ count is known, then use the normalized gain formula to determine the improvement of student learning outcomes. The following is the n-gain formula developed by Hake (1999) which was later modified by Sundayana (2016: 151):

$$
G=\frac{\text { Skor Posttest }- \text { Skor Pretest }}{\text { Skor Ideal }- \text { Skor Pretest }}
$$

After the n-gain is obtained, next is to compare the results obtained with the normalized gain category

\section{RESULTS AND DISCUSSION}

\section{Results}

Test the validity of the test instrument using Product Moment formula. Calculation of validity test is done by using SPSS 22. 5\% significance level with the number of sample 30 that is 0,361 . The use of significance level of $5 \%$ because this research is an educational research which does not require high level of accuracy. A significance level of $5 \%$ or 0.05 means that in this study $95 \%$ of the decision to reject the wrong hypothesis is correct.

From the test of validity, eight questions of pretest and eight posttest questions are valid. From the above questions were taken five of each question pretest and posttest, that is item number $1,2,3,5$, and 6. Item question is selected because of the eight questions, the five questions most meet the basic competence and the problem solving indicators who want achieved in learning.

After passing the validity test question, then performed the reliability test instrument pretest and posttest. The results obtained from the test instrument reliability test (pretest) show the reliability of 0.788 and the test instrument (posttest) shows the reliability of 0.711 . The value is then compared with $r$ table. The $\mathrm{r}$ value of the table at $\mathrm{N}=30$ with a significance level of $5 \%$ is 0.361 . From these results note that ri is greater than rtabel, then the pretest and posttest questions are declared reliable. Based on the clarification table of reliability coefficients

After passing the validity test question, then performed the reliability test instrument pretest and posttest. The results obtained from the test instrument reliability test (pretest) show 
the reliability of 0.788 and the test instrument (posttest) shows the reliability of 0.711 . The value is then compared with $r$ table. The $\mathrm{r}$ value of the table at $\mathrm{N}=30$ with a significance level of $5 \%$ is 0.361 . From these results note ri that is greater than rtabel, then the pretest and posttest questions are declared reliable. Based on the clarification of the reliability coefficient table is known that the test instrument reliability test (pretest and posttest) has a high level of reliable criteria $>0.6$.

After writen down all their ideas and ideas, the teacher chooses one of the students who serve as a note. Group representatives convey the results of their discussions in front of the class and the minutes they write their opinions. Students look very enthusiastic follow the learning process. It can be seen from how they follow the learning with passion, actively ask and answer, can not wait forward to convey the results of discussion. After all opinions are written, the teacher gives a five minute break. The activity is continued by evaluating all the answers. Teachers write their answers on the board, then choose, sort, or combine positive and potential ideas. From these activities there are various answers. From this activity, students know that there are many solutions that can be given from a problem.

At the end of the lesson, the control class students and the experimental class are given posttest. This posttest to find out student learning outcomes after following the learning process by using brainstorming method.

After doing the research the next step is to perform data analysis of research results. The data obtained in this study are the data of learning outcomes in the form of problem-solving skills of students in charge of the IPS material obtained from a given test item prior to treatment (pretest) and after treatment (posttest). The pretest and posttest issues are the same weighted questions to avoid any effect of the difference in the quality of the instrument from the change of knowledge and understanding of students after the treatment.

The test is a five-point description. This test aims to determine the effect that occurs on the results of student problem solving skills on the content of Social Studies material after the treatment in the experimental class group with the control class group as a comparison. Some of the steps taken include homogeneity test, normality test, and Ttest.

\section{Normality test}

Based on data from pretest and posttest result obtained from two class samples that is experiment class and control class, then the normality test is done to know whether the sample in this research has normal distribution. Normality test in this study using Kolmogorov-Smirnov formula with the help of SPSS 22 on the essay to test the distribution of data. The following is the result of normality test done from the result of pretest and posttest value from experiment class and control class.
Based on data from pretest and posttest result obtained from two class samples that is experiment class and control class, then the normality test is done to know whether the sample in this research has normal distribution. Normality test in this study using Kolmogorov-Smirnov formula with the help of SPSS 22 on the essay to test the distribution of data. The following is the result of normality test done from the result of pretest and posttest value from experiment class and control class.

TABLE III

Tests of Normality (Pretest)

\begin{tabular}{|c|r|r|r|r|r|r|}
\hline & \multicolumn{3}{|c|}{$\begin{array}{c}\text { Kolmogorov- } \\
\text { Smirnov }\end{array}$} & \multicolumn{3}{c|}{ Shapiro-Wilk } \\
\cline { 2 - 7 } & $\begin{array}{c}\text { Statis } \\
\text { tic }\end{array}$ & df & Sig. & $\begin{array}{c}\text { Statist } \\
\text { ic }\end{array}$ & df & Sig. \\
\hline $\begin{array}{c}\text { Eksperi } \\
\text { men } \\
\text { Kontrol }\end{array}$ & .149 & 29 & .099 & .902 & 29 & .011 \\
\hline
\end{tabular}

*. This is a lower bound of the true significance.

a. Lilliefors Significance Correction

Based on Table 3 it can be seen that the results of normality test using Kolmogorov-Smirnov test with experiment class significance value of 0.099 while the significance value of control class of 0.076 . Since the significance value for both classes is greater than the 0.05 significance level, it can be concluded that Ho is accepted i.e. the data of problem solving skills pretest comes from the normal distributed population and $\mathrm{Ha}$ is rejected i.e. the problem solving skill of pretest does not come from the normal distributed population.

The results of normality test analysis on the final state (posttest) as follows:

TABLE IV

Tests of Normality (Post Test)

\begin{tabular}{|c|r|r|r|r|r|r|}
\hline \multirow{1}{*}{} & \multicolumn{3}{|c|}{$\begin{array}{c}\text { Kolmogorov- } \\
\text { Smirnov }\end{array}$} & \multicolumn{3}{c|}{ Shapiro-Wilk } \\
\cline { 2 - 7 } & $\begin{array}{c}\text { Statis } \\
\text { tic }\end{array}$ & df & Sig. & $\begin{array}{c}\text { Statis } \\
\text { tic }\end{array}$ & df & Sig. \\
\hline $\begin{array}{c}\text { Eksperi } \\
\text { ment }\end{array}$ & .148 & 29 & .102 & .947 & 29 & .154 \\
Control & .104 & 29 & $.200 *$ & .978 & 29 & .772 \\
\hline
\end{tabular}

a. Lilliefors Significance Correction 
Based on Table 4 it can be seen that the results of normality test using Kolmogorov-Sminov test with experiment class significance value of 0.102 while the value of control class significance of 0.200 . Since the significance value for both classes is greater than the 0.05 significance level, it can be concluded that $\mathrm{Ho}$ is accepted i.e. the data of posttest problem solving skills comes from normally distributed populations and $\mathrm{Ha}$ is rejected ie posttest problem-solving skills do not come from normally distributed populations.

\section{Homogeneity Test}

Homogeneity test is used to determine whether the sample group has identical ability (homogeneous) or not. Homogeneity test was performed by using SPSS 22 program on Levene test. Homogeneity test of data distribution is done on pretest and posttest value data are presented in table as follows.

TABLE V

Test of Homogeneity

Pretest

\begin{tabular}{|c|c|c|c|}
\hline Levene Statistic & df1 & $\mathrm{df} 2$ & Sig. \\
\hline 4.024 & 1 & 57 & .050 \\
\hline
\end{tabular}

Based on Table 5 it can be seen that the significance value of 0.050 . Since the significance value of both classes of initial state is precisely at the 0.05 significance level, it can be concluded that Ho is accepted i.e. the variant of the data population has a homogeneous variant and $\mathrm{Ha}$ is rejected ie the variant of the data population has a different variant. The homogeneity test of the two groups data at the final state is based on the posttest score.

TABLE VI

Test of Homogeneity of Variances Post Test

\begin{tabular}{|c|c|c|c|}
\hline \multicolumn{4}{|c|}{ Post Test } \\
\hline Levene Statistic & df1 & $\mathrm{df} 2$ & Sig. \\
\hline 2.519 & 1 & 57 & .118 \\
\hline
\end{tabular}

Based on Table 6 it can be seen that the significance value of 0.118 . Because the significance value of both classes of final state is greater than the 0.05 significance level, so it can be concluded that Ho accepted that the variant of the data population has a homogeneous variant and $\mathrm{Ha}$ is rejected ie the variant of the data population has a different variant.

\section{Hypothesis test}

After the data has been declared normal distribution, then the next step is to calculate the t-test. In this study used t-test to prove the hypothesis whether or not the influence of the use of brainstorming methods to problem-solving skills on the content of Social Studies theme 8 environment of our friend SDN Gempol 3 Pasuruan. The t-test is used to compare posttest results between control and experiment classes. In this study the t-test test is an Independent Samples T-Test by using SPSS 22. The results of calculations using SPSS 22 can be seen in the following table:

TABLE VII

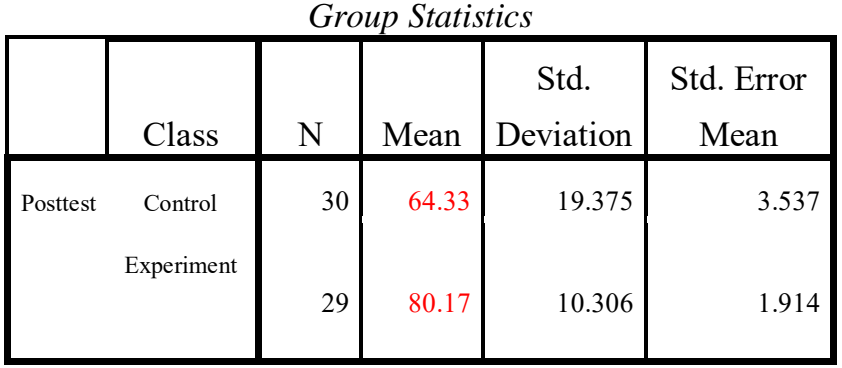

If the value is sig. (2-tailed) less than 0.05 then there is a difference in the effect of the treatment. If greater than 0.05 then there is no effect of the treatment. Based on the result of $t$ test test known sig value. (2-tailed) is $0,000<0.05$, it can be concluded that $\mathrm{Ha}$ is accepted or there is a difference between the posttest result of the experimental class class and the control class posttest. There is a significant influence between giving treatment in the form of using brainstorming method to student problem solving skill.

\section{Normalized N-Gain Test}

In this research, a normalized N-gain test is used to find out how big the improvement of problem solving skills before and after learning by using brainstorming method. The following is the result of normalized $\mathrm{N}$-gain test.

TABLE VII

Normalized N-Gain Test

\begin{tabular}{|c|c|c|c|c|}
\hline \multirow{2}{*}{ Class } & \multicolumn{2}{|c|}{ Mean } & \multirow{2}{*}{ N-Gain } & \multirow{2}{*}{ Category } \\
\cline { 2 - 5 } & Pretest & Posttest & & \\
\hline Control & 57,33 & 64,33 & 0,16 & Medium \\
\hline Experiment & 44,31 & 80,17 & 0,64 & Low \\
\hline
\end{tabular}

Table 8 shows an increase in problem solving skills of students both in the control class and in the experimental class. In control class the gain value obtained is 0.16 with low category. While in the experimental class the gain value obtained is 0.64 . This indicates that the improvement of student problem solving skills in the experimental class is in the medium category.

\section{Discussion}


This experimental research was conducted at SDN Gempol 3 Pasuruan. The process of learning activities carried out in two classes namely class V Flamboyan and class V Kemuning. Where class V Flamboyan as experiment class and class V Kemuning as control class. In this study, the process of learning activities begins with the provision of pretest questions before the students are given treatment, and after that at the end of the process of learning activities students are given posttest to determine whether or not a significant influence from the use of brainstorming methods to student problem solving skills.

Provision of treatment in this study was conducted at the second meeting in each class. The material taught is about "The Influence of Economic Activities on People's Welfare". Provision of treatment in the learning process aims to deepen the material of the basic competencies to be achieved. Next data taking is done through the acquisition of pretest and posttest of students on the content of Social Studies about the influence of economic activities on the welfare of the community. The pretest and posttest results were then analyzed using normality test, homogeneity test, t-test, and n-gain.

Hypothesis test is done after it is known that the data is normal and homogeneous distributed by using independent sample t-test. Calculation of t-test can be known if the value $t_{\text {count }}<-t_{\text {table }}$ and significance $<0,05$. The t-test calculation shows that $t_{\text {count }}-3,900$. The $t$-test value is an empirical $t$-test value which can be consulted with table $\mathrm{t}$ value for $\mathrm{df}=\mathrm{n}-2$ that is $59-2=57$, with $5 \%$ significance level is -2.002 . From these results it is known that $t$ count is smaller than ttable. $\left(\mathrm{t}_{\text {count }}\right.$ $\left.3,900<\mathrm{t}_{\text {table }}-2.002\right)$ and $0,000<0.05$. So it can be concluded that Ho is not proven and hence the hypothesis "The influence of brainstorming method on problem solving skills on content of Social Studies theme 8 environment of our friend SDN Gempol 3 Pasuruan" accepted.

After the calculation of the pretest and posttest results of the two classes that become the research sample, in the control class obtained the average value as in the following table:

TABLE IX

Pretest and Posttest Mean

\begin{tabular}{|c|c|c|}
\hline \multirow{2}{*}{ Class } & \multicolumn{2}{|c|}{ Mean } \\
\cline { 2 - 3 } & Pretest & Posttest \\
\hline Control & 57,33 & 64,33 \\
\hline Experiment & 44,31 & 80,17 \\
\hline
\end{tabular}

Based on table 9 shows pretest and posttest results of both classes have differences. The posttest result of the experimental class is higher than the control class. Here is a comparison chart of the pretest and posttest results obtained in the experimental class and control class.

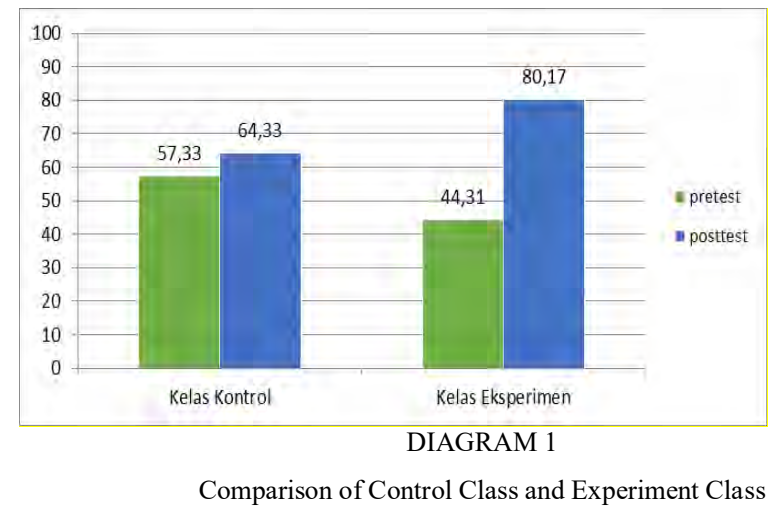

Based on the diagram above, the result of pretest and posttest values of the two classes is different. It is indicated that there has been an increase of pretest and posttest results from both classes, but a higher increase occurs in the experimental class. Where the experimental class is a class that has been through treatment on learning activities. Treatment is the use of brainstorming methods.

In the normalized n-gain test analysis conducted in this study showed that there was an increase in both the control class and the experimental class. The calculation of normalized $\mathrm{n}$-gain test analysis conducted in both classes shows that in the control class there has been an increase of 0.16 with the low category and in the experimental class there has been an increase of 0.64 in the medium category. Although there has been an increase in both classes, the increase in experiment class is higher than the increase in the control class.

At the time of the learning process, researchers apply the brainstorming method in the experimental class according to the rules and the existing stages. In the delivery of materials using brainstorming matrices, researchers invite students to interact with question and answer questions and motivate students to express opinions or ideas as much as possible without any criticism. During the process of learning activities, researchers also provide guidance when students have difficulty.

The problem solving skills of the students in the experimental class which in their learning use the brainstorming method is better than the control class students who do not use the brainstorming method in their learning. This is in accordance with Roestiyah's opinion (2012: 74) that the brainstorming method has advantages that activate students' thinking to express opinions, train students to think logically, children feel free to create an atmosphere of democracy and discipline. Students have applied previously acquired knowledge into a new, unknown state in finding and resolving a problem.

Based on the theory of problem solving and the advantages of brainstorming methods, shows that brainstorming methods affect the problem solving with the activity, creativity and experience of students. Because by giving the problem students will understand the problem then the students express an 
opinion that allows the problem to develop into a new problem or allow for a problem solving.

Based on data analysis and discussion, it can be seen that there are differences in problem solving skills in the experimental class and control class. The experiment class shows a better result average than the control class. So it can be concluded that the method of brainstorming affect the problemsolving skills on the content of IPS theme 8 environment of our friend SDN Gempol 3 Pasuruan.

\section{CONCLUSION}

Based on the results of research and discussion about the influence of brainstorming methods on problem solving skills on the content of IPS theme 8 environment of our friend SDN Gempol 3 Pasuruan, it can be concluded that there is a significant influence of the treatment of student problem solving skills using the brainstorming method. This is evidenced from the calculation of T-Test by using SPSS analysis 22. The result obtained from the calculation is the value of Sig. ( 2 tailed) of 0.000 . Results sig. ( 2 tailed) of 0,000 which means that this value is less than 0.05 where it can be concluded that Ha is accepted and Ho is rejected. The result of the normalized controlled n-gain calculation of the control class shows the number 0.16 which means in the low category and the n-gain of the experimental class is 0.64 which means in the medium category.

\section{Suggestion}

From the above conclusions, here are some suggestions that can be presented from the results of this study:

Brainstorming method can be done in the learning process with the appropriate material, because this learning method emphasizes that students are actively involved in learning activities. In addition, brainstorming methods can be used in the achievement of aspects and other material content, for example in the aspect of creative thinking on the other subject

For further research (other researchers), this research can be used as a reference to understand the use of brainstorming method by using other variables. In addition, in its application should be more able to consider several shortcomings that exist to anticipate the occurrence of things outside the plan, such as aspects of time management. This is caused by some prior preparations on learning activities using brainstorming methods so that teachers or other educators should be able to utilize the time as well as possible.

\section{REFERENCES}

[1] Balitbang Kemendikbud. 2016. TIMSS Infographic.(Online) (http://puspendik.kemdikbud.go.id/seminar/upload/Hasil\%20Semi nar\%20Puspendik\%202016/TIMSS\%20infographic.pdf, accessed 1 September 2018).

[2] Gunansyah, Ganes. 2015. Pendidikan IPS: Berorientasi Praktik yang Baik. Surabaya: Unesa University Press. Hamiyah, Nur dan Jauhar, Muhammad. 2014. Strategi Belajar-Mengajar Di Kelas. Jakarta: Prestasi Pustakaraya.
[3] Marjohan. 2013. Kepatuhan Siswa terhadap Disiplin dan Upaya Guru BK dalam Meningkatkanya melalui Layanan Informasi. Jurnal Ilmiah Konseling, Volume 2, No 1, Januari 2013 (220-224).

[4] NCSS. 2017. Powerful, Purposeful Pedagogy in Elementary School Social Studies. (http://socialstudies.org/positions/powerfulandpurposeful, diakses 5 Februari 2018).

[5] Roestiyah. 2008. Strategi Belajar Mengajar. Jakarta: Rineka Cipta.

[6] Sani, Ridwan Abdullah. 2014. Inovasi Pembelajaran. Jakarta: Bumi Aksara.

[7] Sundayana, Rostina. 2014. Statistika Penelitian Pendidikan. Bandung: Alfabeta.

[8] Trianto. 2011. Mendesain Model Pembelajaran Inovatif-Progresif. Jakarta: Prestasi Pustaka. 